\title{
Photoperiodic regulation of reproductive development in male white-footed mice (Peromyscus leucopus) born at different phases of the breeding season
}

\author{
Nancy G. Forger and I. Zucker \\ Department of Psychology and Group in Endocrinology, University of California, Berkeley, \\ California 94720, U.S.A.
}

\begin{abstract}
Summary. Male white-footed mice were maintained from birth in chambers equipped with latitudinal timers programmed to simulate the natural progression of daylengths at $42^{\circ} \mathrm{N}$ latitude. Mice were born into photoperiods starting on 1 April, $15 \mathrm{July}, 15 \mathrm{Sep}-$ tember or 27 October. Testes and seminal vesicles of April- and July-born mice were mature at 60 days of age; puberty was delayed by several months in animals born into the September and October photoperiods but these mice became fecund at about 3.5 months of age, independent of current photoperiod. Therefore, increasing daylengths of late winter do not appear to synchronize the reproductive development of overwintering juveniles born at different times during the previous breeding season.
\end{abstract}

\section{Introduction}

Seasonal delays in puberty have been demonstrated in temperate-zone rodents and lagomorphs. Young born in spring and early summer reach puberty and breed in the season of their birth; offspring born near the end of the breeding season remain sexually immature throughout the winter and do not become fecund until the following spring (Sadleir, 1969; Worth, Charlton \& MacKinnon, 1973; Lincoln \& MacKinnon, 1976). Similarly, first ovulation is delayed in lambs born in the fall compared to those born in the spring (Foster, 1981). The delay in puberty of lateborn offspring presumably evolved to prevent breeding during unfavourable times of year.

Photoperiod is a proximate factor underlying rates of maturation of the reproductive apparatus. Maintenance in short daylengths (10 h light and $14 \mathrm{~h}$ darkness/day; 10L :14D) from birth delayed gonadal development until about 5 months of age in white-footed mice (Peromyscus leucopus); mice kept in a long photoperiod (14L:10D) were fecund by 60 days of age (Johnston \& Zucker, 1980a). In similar experiments, short daylengths retarded gonadal growth in Microtus agrestis (Grocock, 1981), Microtus arvalis (Lecyk, 1962), Peromyscus maniculatus (Whitsett \& Miller, 1982; Dark, Johnston, Healy \& Zucker, 1983), Phodopus sungorus (Hoffmann, 1978) and Onychomys leucogaster (Frost \& Zucker, 1983). Studies using constant short photophases indicate that daylengths below a minimal duration inhibit reproductive development. However, the direction of change in daylength also carries predictive information. Animals may respond to progressive increases in daylength in late winter and early spring or to decreases in daylength in July and August to achieve seasonally appropriate adjustments in physiology and behaviour. Thus, the effects of photoperiod on body mass and reproductive development of the montane vole, Microtus montanus, vary as a function of an animal's prior photoperiod history. A 14-h photophase is respectively interpreted as a short or a long daylength, depending on whether the animal previously was maintained on 16- or 8-h daylengths (Horton, 1984).

The first phase of this study sought to determine rates of reproductive development of whitefooted mice maintained from birth to 60 days of age in photoperiods that simulate the progression : 32:58AM 
of daylengths at different phases of the breeding season. This procedure more nearly approximates natural conditions and may permit ecologically valid conclusions.

White-footed mice in Michigan breed from March to October (Burt, 1946). The breeding population each spring includes adults recovering from winter gonadal regression, as well as puberty-delayed juveniles born between September and November, and achieving reproductive competence for the first time. It is not known whether onset of reproduction in the spring is synchronized amongst these several groups of animals.

Adult white-footed mice exhibit spontaneous testicular redevelopment a number of weeks after transfer to a constant short photophase (Johnston \& Zucker, 1980b; Lynch \& Wichman, 1981). Eventual development of the gonads also occurs at 4-5 months of age in juvenile mice maintained in constant short days from birth (Johnston \& Zucker, 1980a). If this relation applies to free-living juveniles, then young born in September should become reproductively competent several weeks earlier than mice born in late October. Alternatively, the progressive change in daylength during the winter and early spring might synchronize reproduction amongst these groups of overwintering juveniles. The second phase of the present study attempted to discriminate between these possibilities.

\section{Materials and Methods}

Animals. Adult white-footed mice derived from a wild population trapped near East Lansing, Michigan $\left(42^{\circ} 45^{\prime} \mathrm{N}, 84^{\circ} 30^{\prime} \mathrm{W}\right)$ were housed in polyurethane cages $(27 \times 21 \times 16 \mathrm{~cm})$ in a $14 \mathrm{~L}: 10 \mathrm{D}$ photoperiod. Wood shavings and small glass nest jars were provided and Purina Mouse Chow and water were continuously available. The breeding pairs were primarily first-generation laboratoryborn mice but also included several wild-born animals.

Photoperiods. Experimental mice were housed in light-proof wooden chambers $(1.82 \times 0.63 \times$ $0.5 \mathrm{~m}$ ) illuminated by two $30-\mathrm{W}$ cool white fluorescent bulbs that provided 1400 lux at cage level. Ventilation was provided by a fan in continuous operation and chamber temperature was approximately $23^{\circ} \mathrm{C}$. Daylength in each chamber was controlled by a latitudinal timer (AMF Paragon AstroDial Timer) programmed to simulate the natural progression of daylengths at $42^{\circ} \mathrm{N}$ latitude. Photocells in each chamber, wired to remotely located event recorders, allowed verification of daily light onset and offset.

The initial photoperiods were chosen to simulate daylengths prevailing for mice born during the early, mid-, late and terminal phases of the breeding season of white-footed mice in Michigan. Pregnant mice were assigned to one of four photoperiod conditions midway through gestation and pregnancies were timed so that young in each group were born within a 7-day period. Litters were therefore born into photoperiods mimicking the natural photophases of 1 April, 15 July, 15 September or 27 October ( \pm 3 days) at $42^{\circ} \mathrm{N}$ (see Text-fig. 1). Actual dates of observation did not correspond to the simulated seasons for any group. Animals in the July and September conditions were tested in two replications.

Procedure. Young were weaned at 23 days of age. Male offspring remained in the chambers, housed 2 per cage, while dams and female young were removed from the room housing the chambers. When the males were about 60 days of age (57-63 days), a random sampling of those born into the July, September and October photoperiods, and all animals born into the April photoperiod, were killed. The seasonal progression of photoperiods was continued after the age of 60 days for mice from the July, September and October groups. Additional mice were killed when each group reached photoperiods typical of 27 December, 1 February, 15 February, 1 March and 15 March. Representative mice from the September and October groups also were killed at the time of the 30 March photoperiod.

At the time of autopsy, mice were administered a lethal dosage of pentobarbitone sodium. Body 
weight $( \pm 0 \cdot 1 \mathrm{~g})$, paired testes weight and seminal vesicle weight $( \pm 0 \cdot 1 \mathrm{mg})$ were recorded. Testes were fixed in buffered formalin, dehydrated, embedded in paraffin wax, sectioned at $5 \mu \mathrm{m}$ and stained with haematoxylin and eosin. Testicular development was assessed by scoring (1) seminiferous tubule diameter (scale of 1 to $100 ; 100=250 \mu \mathrm{m}$ ) and (2) the percentage of tubules containing mature spermatozoa, as determined from examination of at least 40 seminiferous tubules. A composite spermatogenic rating was then assigned to each animal by averaging these two scores. Spermatogenic ratings $<39$ were always associated with testes completely devoid of spermatozoa, while testes with at least some mature spermatozoa received scores between 39 and 94. This rating system was employed instead of the more commonly used spermatogenic index (Grocock \& Clarke, 1974; Johnston \& Zucker, 1980b) to provide a more quantitative measure of testicular maturation that distinguishes fine gradations in development.

One and two-way analyses of variance (ANOVA) were used to evaluate the significance of treatment effects and differences between groups when appropriate. Several reproductive characteristics were compared for selected groups at 60 days of age with $t$ tests using pooled variance estimates (planned comparisons).

\section{Results}

The photoperiod durations in the chambers did not differ by more than 10-15 min from natural daylengths at $42^{\circ} \mathrm{N}$ (Text-fig. 1).

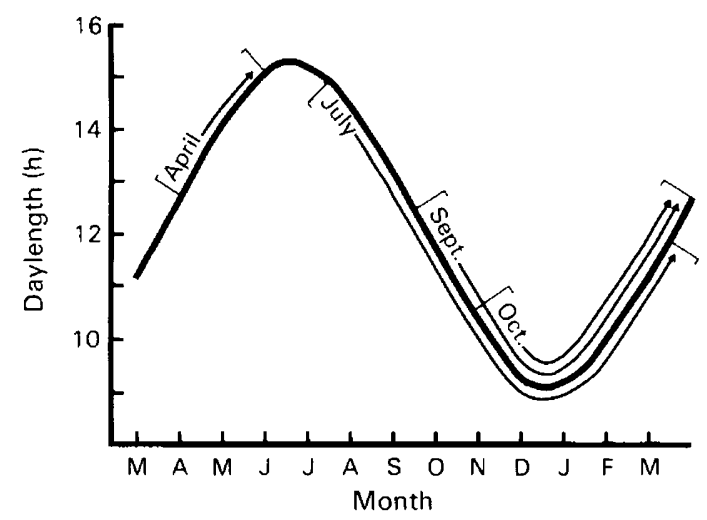

Text-fig. 1. Daylengths for mice born into 1 April, 15 July, 15 September and 27 October photoperiods. Values are for Jackson, Michigan $\left(42^{\circ} 15^{\prime} \mathrm{N}\right)$ and were obtained from the U.S. Nautical Almanac Report.

\section{Development at 60 days of age}

Photoperiod influenced reproductive development during the first 60 days; analysis of variance revealed significant effects on testicular weights $(P<0.001$; Text-fig. $2 \mathrm{a})$, seminal vesicle weights ( $P<0.001$; Text-fig. 2b) and spermatogenic rating $(P<0.001$; Text-fig. $2 \mathrm{c})$.

Mice born into the April and July conditions experienced opposite progressions of photoperiod; daylengths increased from 12.7 to $15.0 \mathrm{~h}$ for the April-born animals and decreased from 15.0 to 12.6 $\mathrm{h}$ for the July-born cohort during the first 60 days of life. April-born mice had the heaviest testes and seminal vesicles as well as the highest spermatogenic ratings. The July group had testes weights comparable to those of April mice; however, seminal vesicle weights and the spermatogenic ratings were lower for July- than for April-born mice ( $P<0.02 ; P<0.004$, respectively). 

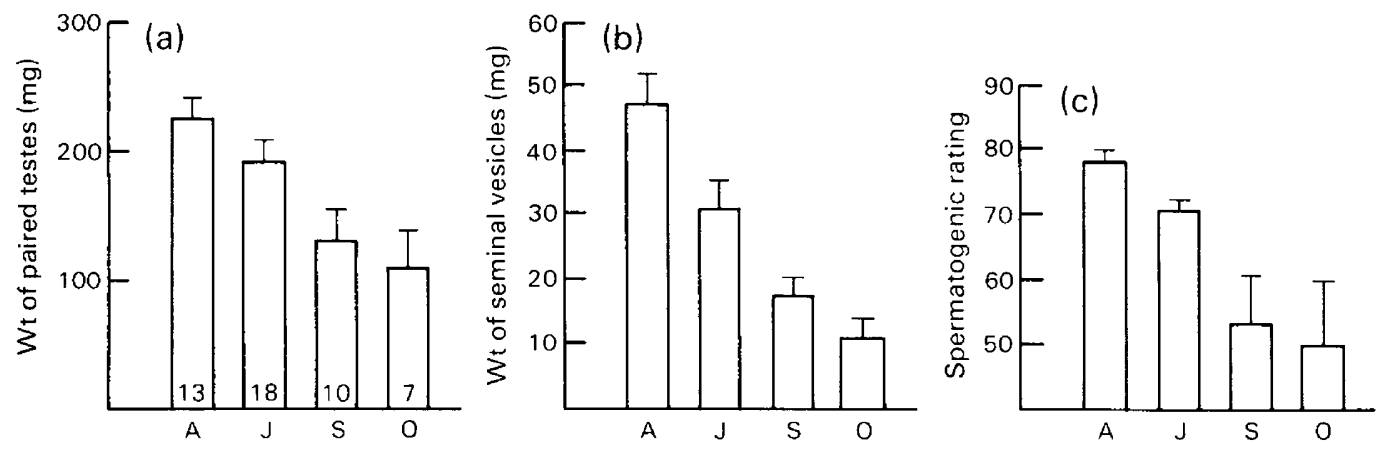

Text-fig. 2. Weights of the testes (a) and seminal vesicles (b) and spermatogenic ratings (c) of white-footed mice at 60 days of age after being born into daylengths simulating those of 1 April, 15 July, 15 September or 27 October. Values are mean \pm s.e.m. for the samples sizes indicated.

The reproductive systems of April and July-born mice were more developed than were those of mice born into the September or October photoperiods. The September and October groups did not differ significantly from each other on any measure at 60 days, but testicular weights, seminal vesicle weights and spermatogenic ratings were lower than in April- and July-born mice $(P<0.001$ for each value). The various groups did not differ with respect to body weight throughout the study ( $F$ $=0.78, P>0.05)$ or at 60 days of age $(\mathrm{F}=1.94, P>0.05)$.

\section{Development beyond 60 days of age}

Mice born into the July, September and October photoperiods were killed at predetermined times until 30 March photoperiod conditions were reached. April-born mice were not tested during this phase of the study. Compared to the relatively high values recorded in September (60 days of age), testes of July-born mice were substantially reduced in weight at 15 October, 27 December and 1 February photoperiods; gonadal weight increased again at the daylengths of 15 February, 1 March and 15 March (Text-fig. 3a). This pattern was similar to that manifested by adult mice whose relatively well developed testes undergo regression in the short daylengths of autumn and redevelopment in the late winter and early spring.

Based on histological and tissue weight criteria, the reproductive apparatus was minimally developed during the first 60 days of life in mice born into the October photoperiod; testes first showed signs of significant growth at the 15 February photoperiod and gonadal weights remained elevated at subsequent samplings. Reproductive development of the July- and October-born mice was similar between December and 15 March $(P>0.05$ for testes weights, spermatogenic ratings and seminal vesicle weights), but the developmental pattern in both groups was significantly different from that of mice born into the September photoperiod.

Mean testicular weights of the September-born mice began increasing by late December and reached adult size by 1 February. The same pattern was observed for spermatogenic ratings (Textfig. 3b) and seminal vesicle weights. Development of the reproductive system differed between September and October-born mice between 27 December and 30 March $(P<0.002$ for all values, F-tests). Much of the difference reflected the earlier maturation of the September mice; between 27 December and 1 February, the September- and October-born mice differed in testicular weight $(P$ $<0.02)$, seminal vesicle weights $(P<0.03)$ and spermatogenic rating $(P<0.01)$. The groups did not differ at the time of the 15 February photoperiod, or at the time of the final observation (30 March).

The reproductive system matured at different times of year, corresponding to different photophase durations, in mice born late (September) or very late (October) in the breeding season, al- 


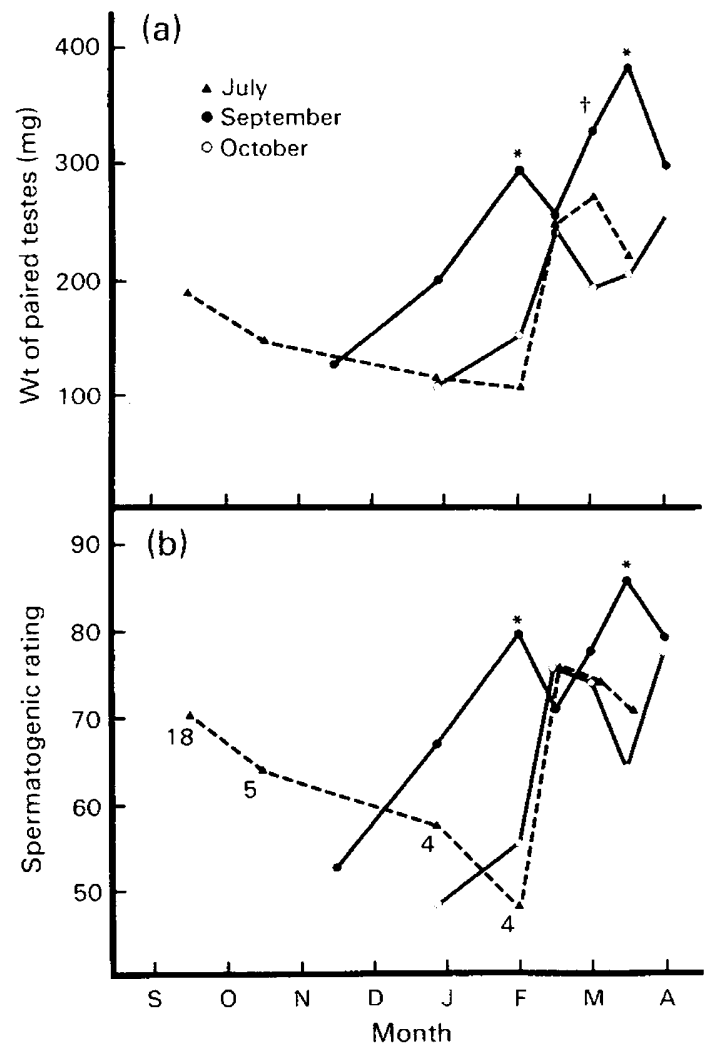

Text-fig. 3. Paired testes weights (a) and spermatogenic ratings (b) at different simulated calendar dates. Mice were born into the photoperiods of $15 \mathrm{July,} 15$ September or 27 October and killed on the dates indicated. $N=6-10$ per group except as otherwise indicated; for ease of visualization standard errors are not shown. ${ }^{*}$ Significantly different $(P<0.05)$ from July and October values. $\uparrow$ Different from October value only $(P<0.05)$. July and October not different at any point.
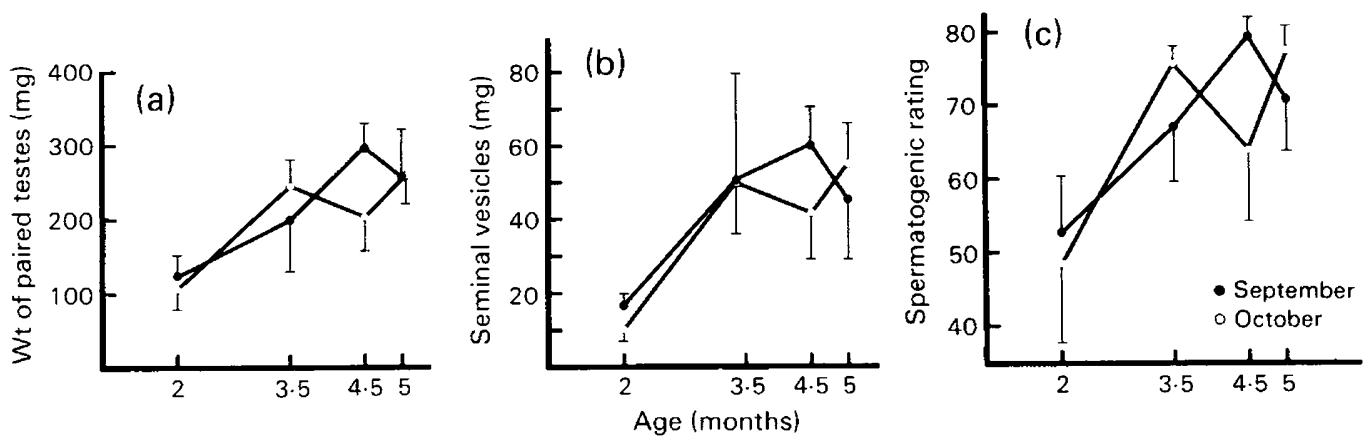

Text-fig. 4. Paired testicular weights (a), seminal vesicle weights (b) and spermatogenic ratings (c) at different ages for mice born into 15 September and 27 October photoperiods. Values are mean \pm s.e.m. for 6-10 mice/group. 
though age at puberty was similar for the two groups. Data collected at 2, 3.5, 4.5 and 5 months of age indicate that September and October-born mice achieved sexual maturity at comparable rates $(P>0.05$ for all values measured, Text-fig. 4$)$ and at about 3.5 months of age.

\section{Discussion}

Autumn photoperiods delayed puberty in white-footed mice, although eventual maturation of the reproductive apparatus in animals born into photoperiods characteristic of the later part of the breeding season was independent of daylength. Mice born into 15 September and 27 October photoperiods attained sexual maturity at the same age, rather than at a given photophase duration or time of year. Extrapolation to free-living mice suggests a lack of synchronization by photoperiod of reproductive development in litters born 1 week before and 5 weeks after the autumnal equinox. During the ensuing spring, animals born in September presumably can breed more than a month in advance of mice born at the end of October.

In contrast to the puberty delay seen in September- and October-born mice, mice born into the April and July photoperiods were sexually mature by 60 days of age. The reproductive apparatus of July-born mice then followed the expected adult pattern: regression during autumn photoperiods and redevelopment beginning in winter, while daylengths were still very short. Gonadal redevelopment in the adult July-born mice and attainment of puberty in October-born juveniles occurred at similar photoperiods, while September-born animals achieved reproductive competence significantly earlier in the simulated year. Separate populations of early and later breeding individuals have been described in free-living Peromyscus (Fairbairn, 1977, and references therein); however, the age and previous sexual development of the animals in this field study were not known.

Although constant short photophases effectively delay sexual maturation in several photoperiodic rodent species (Zucker, Johnston \& Frost, 1980), complete spermatogenesis is evident by 5 months of age (Hoffmann, 1978; Johnston \& Zucker, 1980a; Frost \& Zucker, 1983). Attainment of puberty by juvenile animals kept in short daylengths closely parallels the spontaneous redevelopment of the reproductive apparatus observed in adult rodents during longterm maintenance in short photophases (see Zucker et al., 1980). The analogy between delayed first-time development and spontaneous redevelopment can now be extended to animals maintained in photoperiods that simulate natural daylengths. It is possible that increases in daylength after the winter solstice in the present study and in the field may accelerate reproductive maturation relative to that of mice maintained in constant short daylengths (see Johnston \& Zucker, 1980a).

The pineal gland mediates the effects of short days on sexual maturation of white-footed mice (Johnston, Boshes \& Zucker, 1982). Pinealectomized mice kept in short daylengths from birth reach puberty at the same age as intact animals kept in long photophases. Furthermore, implants of melatonin delay puberty in mice housed in long photophases (Petterborg \& Reiter, 1980, 1982). Eventual maturation of the gonads in juveniles born late in the breeding season, and spontaneous redevelopment in over-wintering adults, probably reflect neuroendocrine refractoriness to the antigonadal effects of melatonin (Bittman, 1978; Zucker et al., 1980).

Young born late in the breeding season experience short daylengths that do not support reproductive development. The critical photoperiod adequate for rapid development of the reproductive system is not known for Michigan white-footed mice. Animals born into a 15 July photoperiod achieved sexual maturity at an early age whereas mice born into a 15 September daylength did not; the minimal daylength sufficient for rapid development of the reproductive apparatus presumably occurs between the photophases of these dates (15.0-12.6 h light/day). In studies of adult Connecticut white-footed mice, Lynch \& Gendler (1980) did not establish a precise 'critical' daylength for gonadal regression; rather, gonadal involution gradually became more probable in progressively shorter daylengths. The relatively large standard errors reported in our study attest to 
the considerable individual variability in response to a given progression of photoperiods, and also argue against a strict 'critical daylength' in this species.

At 60 days of age the reproductive apparatus of April-born mice was significantly more developed than that of July-born animals. The two groups experienced the same photophases, albeit in reversed order. One possible explanation is that the direction of daylength change may affect the rate of reproductive maturation. Specifically, increases in daylength may stimulate development even when the absolute duration of the photophase is relatively short; conversely, decreases in the daily photophase may initiate reproductive involution even when the absolute photophase duration is above the critical daylength (Horton, 1984). Long but decreasing daylengths, such as occur in July, may be less stimulatory to the reproductive system than the shorter but increasing daylengths of April. Alternatively, exposure of the April-born mice to very long daylengths just before death may explain their accelerated development.

We did not assess the impact of environmental factors other than photoperiod on sexual maturation. While photoperiod alone does not seem to influence gonadal growth during the late winter months, other aspects of the environment may act in concert with increasing daylengths to synchronize reproductive development among overwintering juveniles. Field data for the brown hare, Lepus europaeus, suggest that adults as well as juveniles born at different times throughout the breeding season are synchronized with respect to gonadal development in the spring (Lincoln \& Mackinnon, 1976). The basis of the contrasting findings for hares and white-footed mice is not known; perhaps non-photoperiodic factors are significant in synchronizing hares. Food availability (Negus, Berger \& Forslund, 1977; Berger, Negus, Sanders \& Gardner, 1981; Nelson, Dark \& Zucker, 1983; Eskes, 1983; Blank \& Desjardins, 1984), ambient temperature (Desjardins \& Lopez, 1980) and social factors (Whitsett \& Lawton, 1982) all modulate the effects of photoperiod on the reproductive system. Nevertheless, the evidence to date indicates that variation in daylength is probably the primary proximate cue used by white-footed mice in timing seasonal cycles.

This research was supported by Grant HD-02982 from the National Institute of Child Health and Human Development and by a National Science Foundation Graduate Fellowship (1-78200021604). We thank Darlene Frost for technical assistance and John Dark, Theresa Lee, Paul Licht and Catherine Weiner for comments on an earlier version of the manuscript.

\section{References}

Berger, P.J., Negus, N.C., Sanders, E.H. \& Gardner, P.D. (1981) Chemical triggering of reproduction in Microtus montanus. Science, N.Y. 214, 69-70.

Bittman, E.L. (1978) Hamster refractoriness: the role of insensitivity of pineal target tissues. Science, N.Y. 202, 648-650.

Blank, J.L. \& Desjardins, C. (1984) Spermatogenesis is modified by food intake in mice. Biol. Reprod. 30, $410-415$.

Burt, W.H. (1946) The Mammals of Michigan. Ann Arbor, University of Michigan Press.

Dark, J., Johnston, P.G., Healy, M. \& Zucker, I. (1983) Latitude of origin influences photoperiodic control of reproduction of deer mice (Peromyscus maniculatus). Biol. Reprod. 28, 213-220.

Desjardins, C. \& Lopez, M.J. (1980) Sensory and nonsensory modulation of testis function. In Testicular Development, Structure and Function, pp. 381-388. Eds A. Steinberger \& E. Steinberger. Raven Press, New York.

Eskes, G.A. (1983) Gonadal responses to food restriction in intact and pinealectomized male golden hamsters. J. Reprod. Fert. 68, 85-90.

Fairbairn, D.J. (1977) Why breed early : a study of reproductive tactics in Peromyscus. Can. J. Zool. 55, 862 871.

Foster, D.L. (1981) Mechanism for delay of first ovulation in lambs born in the wrong season (fall). Biol. Reprod. 25, 85-92.

Frost, D. \& Zucker, I. (1983) Photoperiod and melatonin influence seasonal gonadal cycles in the grasshopper mouse (Onychomys leucogaster). J. Reprod. Fert. 69, 237-244.

Grocock, C.A. (1981) Effect of different photoperiods on testicular weight changes in the vole, Microtus agrestis. J. Reprod. Fert. 62, 25-32.

Grocock, C.A. \& Clarke, J.R. (1974) Photoperiodic control of testis activity in the vole, Microtus agrestis. J. Reprod. Fert. 39, 337-347.

Hoffmann, K. (1978) Effects of short photoperiods on puberty, growth and moult in the Djungarian hamster (Phodopus sungorus). J. Reprod. Fert. 54, 29-35. 
Horton, T.H. (1984) Growth and reproductive development of male Microtus montanus is affected by the prenatal photoperiod. Biol Reprod. 31 (in press).

Johnston, P.G. \& Zucker, I. (1980a) Photoperiodic regulation of reproductive development in whitefooted mice (Peromyscus leucopus). Biol. Reprod. 22, 983-989.

Johnston, P.G. \& Zucker, I. (1980b) Photoperiodic regulation of the testes of adult white-footed mice (Peromyscus leucopus). Biol. Reprod. 23, 859-866.

Johnston, P.G., Boshes, M. \& Zucker, I. (1982) Photoperiodic inhibition of testicular development is mediated by the pineal gland in white-footed mice. Biol. Reprod. 26, 597-602.

Lecyk, M. (1962) The effect of the length of daylight on reproduction in the field vole, Microtus arvalis Pall. Zool. polon. 12, 189-222.

Lincoln, G.A. \& MacKinnon, P.C.B. (1976) A study of seasonally delayed puberty in the wild hare, Lepus europaeus. J. Reprod. Fert. 46, 123-128.

Lynch, G.R. \& Gendler, S.L. (1980) Multiple responses to different photoperiods occur in the mouse, Peromyscus leucopus. Oecologia 45, 318-321.

Lynch, G.R. \& Wichman, H.A. (1981) Reproduction and thermoregulation in Peromyscus: effects of chronic short days. Physiol. Behav. 26, 201-205.

Negus, N.C., Berger, P.J. \& Forslund, L.G. (1977) Reproductive strategy of Microtus montanus. J. Mammal. 58, 347-353.

Nelson, R.J., Dark, J. \& Zucker, I. (1983) Influence of photoperiod, nutrition and water availability on reproduction of male California voles (Microtus californicus). J. Reprod. Fert. 69, 473-477.
Petterborg, L.J. \& Reiter, R.J. (1980) Effect of photoperiod and melatonin on testicular development in the white-footed mouse, Peromyscus leucopus. $J$. Reprod. Fert. 60, 209-212.

Petterborg, L.J. \& Reiter, R.J. (1982) Effect of photoperiod and pineal indoles on the reproductive system of young male white-footed mice. J. Neural Trans. 55, 149-155.

Sadleir, R.M.F.S. (1969) The Ecology of Reproduction in Wild and Domestic Mammals. Methuen, London.

Whitsett, J.M. \& Lawton, A.D. (1982) Social stimulation of reproductive development in male deer mice housed on a short day photoperiod. J. comp. Physiol. Psychol. 96, 416-422.

Whitsett, J.M. \& Miller, L.L. (1982) Photoperiod and reproduction in female deer mice. Biol. Reprod. 26, 296-304.

Worth, R.W., Charlton, H.M. \& MacKinnon, P.C.B. (1973) Field and laboratory studies on the control of luteinizing hormone secretion and gonadal activity in the vole, Microtus agrestis. J. Reprod. Fert., Suppl. 19, 89-99.

Zucker, I., Johnston, P.G. \& Frost, D. (1980) Comparative, physiological and biochronometric analyses of rodent seasonal reproductive cycles. Prog. Reprod. Biol. 5, 102-133.

Received 30 May 1984 